\title{
A responsabilidade civil na concessão do empréstimo consignado: uma análise do superendividamento do servidor publico no estado de Rondônia
}

\author{
The civil liability on the loan consignment: um analisys on the overdebt of the \\ Rondonia states public server
}

\author{
Francele Moreira Marisco ${ }^{1}$ \\ Rayanne Mendes Pereira Fernandes ${ }^{2}$
}

\begin{abstract}
Resumo
A democratização do crédito ao consumidor tem gerado impactos negativos na denominada sociedade de consumo, uma vez que, a outorga do crédito é realizada sem qualquer medida aliada a uma aquisição irrefletida, comprometendo seriamente sua saúde financeira através do superendividamento. Eis a necessidade de medidas legais para a prevenção e controle deste produto/serviço chamado empréstimo consignado, destinado especialmente ao servidor público, e por esta razão o Estado de Rondônia, a exemplo de outros entes federativos, criou a Lei Complementar n.o 622 de 11 de julho de 2011, instituindo a Comissão Especial de Consignações - CECON. O enfrentamento da matéria é necessário, discernindo a quem compete responsabilidade quanto a eventual violação aos preceitos do Código de Defesa do Consumidor nesta relação quando envolve o servidor público estadual.
\end{abstract}

Palavras-chave: Empréstimo Consignado. Lei Estadual. Responsabilidade.

\section{Abstract}

The democratization face to the credit directed to the consumer has generated negative impacts to the consumer society, since the granting of credit is made without any action, combined with a thoughtless acquisition, seriously compromising their financial health through indebtedness. Here is the need of legal measure to prevent and control the product/service called payroll loan, designed especially to civil servants, and, for this reason, the state of Rondônia, like other federal entities, created the Complementary Law n. 622, of July 11, 2011, establishing the Special Committee on Consignment - CECON. Facing the matter is necessary, which is responsible for discerning liability for any violation of the provisions of the Code of Consumer Protection in this relationship, when it involves state public server.

1 Mestre pela Universidade do Vale do Rio dos Sinos/UNISINOS (2009), especialista em Direito do Consumidor pela Universidade de Coimbra/Portugal (2006). Tem experiência na área de Direito, com ênfase em Direito Constitucional, Direito do Consumidor e Direito Processual Civil. Professora do Centro Universitário Luterano de Ji-Paraná (RO) - ULBRA e Coordenadora de Pesquisa do Curso de Direito da ULBRA/Ji-Paraná.

2 Centro Universitário Luterano de Ji-Paraná (CEULI-ULBRA). 
A Responsabilidade civil na concessão do empréstimo consignado: uma análise do superendividamento do servidor público no estado de Rondônia

Keywords: Payroll Loan. State Law. Responsibility.

\section{Introdução}

No ano em que completa 22 anos de vigência, o Código de Defesa do Consumidor além de importantes conquistas possui desafios que se agigantam frente à dinamicidade da sociedade de consumo.

Um destes desafios foi enfrentado pelo Superior Tribunal de Justiça quando editou a súmula 297 em que consagra as instituições financeiras na relação de consumo.

Pelo princípio da vulnerabilidade do consumidor e a facilidade de crédito do mundo moderno, tem sido necessário o enfrentamento da matéria no que tange ao superendividamento. E esse problema tem atingindo de forma tenaz os servidores públicos, tanto que os Governos Estaduais têm tomado medidas de limitação ao crédito consignado.

Este trabalho procura estudar a responsabilidade civil das partes envolvidas quanto à eventual infração ao direito do consumidor diante das normas para consignações em folha de pagamento dos servidores públicos do Estado de Rondônia, estabelecida pela Lei Complementar 622 de 11 de julho de 2011.

\section{A relação de consumo e as instituições financeiras}

Em meio aos princípios da ordem econômica, tal como previstos pela Constituição da República, se encontra o princípio da "defesa do consumidor" (art. 170, V), defesa esta que ainda foi consagrada no Título II da Carta Magna, dedicado aos "direitos e garantias fundamentais", onde prevê que "o Estado promoverá, na forma da lei, a defesa do consumidor" (art. 5ํ, XXXII). Assim, é possível afirmar que o constituinte originário reconheceu a vulnerabilidade do consumidor e por esta razão estabeleceu, com prioridade, a necessidade de elaboração de uma lei que tutelasse este ente ${ }^{3}$.

Com a promulgação do Código de Defesa do Consumidor houve o reconhecimento desta mesma vulnerabilidade, conforme dispõe art. 4 o, inciso $\mathrm{I}^{4}$. O referido diploma trouxe,

3 Art. 48 do Ato das Disposições Constitucionais Transitórias (ADCT): O Congresso Nacional, dentro de cento e vinte dias da promulgação da Constituição, elaborará código de defesa do consumidor.

4 A Política Nacional das Relações de Consumo tem por objetivo o atendimento das necessidades dos consumidores, o respeito à sua dignidade, saúde e segurança, a proteção de seus interesses econômicos, a melhoria da sua qualidade de vida, bem como a transparência e harmonia da relações de consumo, atendidos os seguintes princípios: I - reconhecimento da vulnerabilidade do consumidor no mercado de consumo. 
entre suas finalidades, a busca do equilíbrio entre as partes de uma relação jurídica naturalmente desequilibrada.

Com efeito, ganha relevância a função social do contrato frente a relação jurídica de consumo e neste sentido o próprio $C D C$ consagra, em um rol não exaustivo, uma série de cláusulas contratuais reputadas abusivas", as quais são consideradas "nulas de pleno direito".

Diante desta relação de consumo, importante trazer à baila a definição de consumidor e fornecedor.

Conforme aponta a interpretação realizada por Rizzatto Nunes (2000, p. 117-121) a definição de consumidor restrita, por oportuno, ao artigo 20 da Lei 8.078/90, é aquele que adquire concretamente um produto ou um serviço e que seja destinatário final.

Por sua vez, o fornecedor são pessoas, empresas públicas ou particulares, nacionais ou estrangeiras que oferecem produtos ou serviços para os consumidores ${ }^{6}$.

O legislador a fim de assegurar quem seja o fornecedor de serviços, elenca no parágrafo 2 ㅇ do artigo 3 que os serviços de natureza bancária, financeira, de crédito e securitária são também protegidos pelo Código de Defesa do Consumidor.

Apesar da clareza da lei, houve uma tentativa judicial de obter declaração em sentido oposto, e com redundância à norma legal, em 2004 o Superior Tribunal de Justiça editou a Súmula 297 com o seguinte teor: “O Código de Defesa do Consumidor é aplicável às instituições financeiras".

Não obstante, a manifestação do STJ tramitava ainda a ADIN n.o 2.591 proposta pela Confederação Nacional do Sistema Financeiro, cuja pretensão era a de ver excluída a incidência do Código de Defesa do Consumidor nas operações de natureza bancária, financeira, de crédito e securitária, prevista, sob o argumento de que tal dispositivo estaria viciado por inconstitucionalidade formal e material.

Porém, nos termos em que assegura Rizzatto Nunes (2007, p. 117-121) o CDC não estabelece normatização para relações diversas, existentes entre os vários grupos econômicos, não havendo que se falar em inconstitucionalidade. 
A Responsabilidade civil na concessão do empréstimo consignado: uma análise do superendividamento do servidor público no estado de Rondônia

E, portanto, o colendo Superior Tribunal Federal julgou improcedente a Ação Direta de Inconstitucionalidade $\mathrm{n}$. 2.591 , cujo acórdão foi publicado em 29/09/2006 sujeitando as instituições financeiras à tutela do Código de Defesa do Consumidor e determinando que o Banco Central exerça o controle e revisão das suas operações, incluindo, portanto, as taxas de juros, sem prejuízo da intervenção do Poder Judiciário, em cada caso, realizar um novo exame corrigindo eventual abusividade, onerosidade excessiva ou outras distorções na composição contratual ${ }^{7}$.

Restou evidente a legitimidade da Lei 8.078/90 em regular as relações jurídicas no pólo final de consumo, tornando-se pacificado o entendimento de que o contrato celebrado pelo banco com um particular, em que seja destinatário final, submete-se ao regramento especial do Código de Defesa do Consumidor.

Importante ressaltar que para a doutrina (MARQUES, 2006, p. 83-84), destinatário final do produto ou serviço é o consumidor final de fato e econômico. De fato porque o bem será para seu uso pessoal, consumidor final econômico porque o bem adquirido não será utilizado ou aplicado em qualquer finalidade de produção, tendo seu ciclo econômico encerrado na pessoa que o adquire, entendimento conhecido como Teoria Finalista ou Subjetivista.

Entretanto, o Superior Tribunal de Justiça ${ }^{8}$, de um modo geral, tem considerado a Teoria Finalista Mitigada, ou seja, será consumidor tanto a pessoa que adquire para o uso pessoal quanto os profissionais liberais e os pequenos empreendimentos que conferem ao bem adquirido a participação no implemento de sua unidade produtiva (como por exemplo a aquisição de um microcomputador para controle das finanças da empresa), desde que, nesse caso, demonstrada a hipossuficiência, senão se fará necessário que a relação seja regida pelo Código Civil (SUPERIOR TRIBUNAL DE JUSTIÇA, 2010).

É direito básico do consumidor, elencado pelo art. 6o do CDC a modificação de cláusulas contratuais que estabeleçam prestações desproporcionais ou sua revisão em razão de fatos supervenientes que as tornem excessivamente onerosa.

SUPERIOR TRIBUNAL DE JUSTIÇA. Recurso Especial n.o 716.877 - SP (2005/0004852-3). Min. Rel. Ari Pargendler. Civil. Relação de consumo. Destinatário final. A expressão destinatário final, de que trata o art. 2ㅇ, caput, do Código de Defesa do Consumidor abrange quem adquire mercadorias para fins não econômicos, e também aqueles que, destinando-os a fins econômicos, enfrentam o mercado de consumo em condições de vulnerabilidade; espécie em que caminhoneiro reclama a proteção do Código de Defesa do Consumidor porque o veículo adquirido, utilizado para prestar serviços que the possibilitariam sua mantença e a da família, apresentou defeitos de fabricação. Recurso especial não conhecido. 
Em ambas as teorias, o destinatário final não utiliza do produto (uma mercadoria colocada a venda no mercado) ou serviço (tudo aquilo que se paga para ser feito) como insumo, ou seja, não obtém lucro, e deve ser demonstrada a verdadeira necessidade deste consumidor a fim de se valer do Código de Defesa do Consumidor.

No tocante $a$ isto, entendemos que o empréstimo consignado se enquadra como uma prestação de serviço de natureza financeira e tal qual deve ser tutelado pela lei 8.078/90, até porque a própria lei mencionada conceitua como serviço, as atividades de natureza bancária, financeira, de crédito e securitária ${ }^{9}$.

\section{0 empréstimo consignado e a Lei Complementar do estado de Rondônia N. $622 / 2011$}

Diante da era do crédito, ilustrada por consumidores seduzidos pela publicidade e pelo acesso fácil ao dinheiro, vivemos concomitantemente na sociedade do endividamento.

O empréstimo consignado tem sido comumente utilizado pelo consumidor, como um meio mais rápido e fácil de obtenção de bens e fruição de serviços, ou como uma alternativa para saldar dívidas anteriormente adquiridas.

Segundo dados divulgados no 270 Congresso de Direito do Consumidor o economista da Federação Brasileira de Bancos/FEBRABAN Rubens Sanderberg, revelou que atualmente o mercado de crédito no Brasil é bastante segmentado, ou seja, dos $R \$ 582,7$ bilhões utilizados pelas pessoas físicas, $37 \%$ se destina ao empréstimo consignado, $32 \%$ ao leasing de veículo, $3 \%$ cheque especial, $6 \%$ ao cartão de crédito, $5 \%$ cooperativas, $2 \%$ financiamento de imóveis, $2 \%$ aquisição de outros bens e $13 \%$ outros interesses (informação verbal)(SANDERBERG, 2011).

Em que pese a aparente facilidade e segurança no ato de obtenção, o crédito consignado, tem sido objeto de inúmeras ações judiciais no Brasil, nas quais se pleiteia, na maioria das vezes, o cancelamento unilateral dos descontos, principalmente, porque os consumidores atingiram um nível tal de endividamento que sequer conseguem adquirir produtos indispensáveis à sua sobrevivência, face ao comprometimento de grande parte do salário, remuneração ou benefício previdenciário, descontada mensalmente.

$9 \quad$ Art. 3ㅇ, § 2o, da Lei 8.078/90. 
A Responsabilidade civil na concessão do empréstimo consignado: uma análise do superendividamento do servidor público no estado de Rondônia

Neste sentido o Ministro do Superior Tribunal de Justiça, Paulo de Tarso Sanseverino, no Recurso Especial n. 1.133.180, entendeu pela limitação em 30\% (trinta por cento) dos descontos a serem realizados na folha de pagamento, observando a preservação do mínimo existencial do devedor/servidor público ${ }^{10}$.

E ainda, o Tribunal de Justiça do Estado de Rondônia, nos casos de superendividamento, tem entendido que a limitação dos descontos deve ocorrer seguindo as limitações do STJ, em 30\%, respeitando-se o princípio da dignidade (Art. 1ํ, III, CF/88) e a boa-fé objetiva nas relações de consumo que impõe conduta de lealdade e cooperação com o hipossuficiente ${ }^{11}$.

A título de exemplo da gravidade em que se tornou o superendividamento, o Tribunal de Justiça do Estado do Rio de Janeiro decidiu Recurso ${ }^{12}$ o qual revelava que uma

10 SUPERIOR TRIBUNAL DE JUSTIÇA. Recurso Especial no 1.133.180 - SP (2009/0064805-7), Rel. Min. Paulo de Tarso Sanseverino. Recurso Especial. Crédito consignado. Contrato de mútuo. Desconto em folha de pagamento. Possibilidade. Limitação da margem de consignação a $30 \%$ da remuneração do devedor. Superendividamento. Preservação do mínimo existencial. Ofensa a dispositivos constitucionais. Inviabilidade. Usurpação de competência do supremo tribunal federal. Prequestionamento. Ausência. Súmulas 282 e 356/STF.

11 TRIBUNAL DE JUSTIÇA DO ESTADO DE RONDÔNIA. Agravo de instrumento. Antecipação de tutela. Contrato de empréstimo consignado. Parcelas. Limitação ao teto de $30 \%$ dos vencimentos do contratante. Reversibilidade da medida. Possibilidade. Reforma da decisão agravada. É possível a concessão da antecipação de tutela com objetivo de reduzir o percentual de descontos consignados em vencimentos mensais para patamar que se adeque ao teto de $30 \%$ previsto nas normas regulamentadoras, até que se julgue o mérito da ação principal de revisão de contrato, a fim de preservar a subsistência do devedor. Acórdao. Vistos, relatados e discutidos estes autos, acordam os Desembargadores da 2a Câmara Cível do Tribunal de Justiça do Estado de Rondônia, na conformidade da ata de julgamentos e das notas taquigráficas em, por unanimidade, dar provimento ao recurso nos termos do voto do relator. Porto Velho, 25 de maio de 2011. Desembargador Marcos Alaor Diniz Grangeia (presidente). Autos n. 000551666.2010.8.22.0000. Agravante: Marcos Roberto Pereira Santos. Agravado: HSBC Bank Brasil S/A - Banco Múltiplo. Agravado : Banco Daycoval S/A.

12 TRIBUNAL DE JUSTIÇA DO ESTADO DO RIO DE JANEIRO. Recurso de Apelação, autos n. 2008.001.10460 Apelação Cível. Recurso Adesivo. Ação de Nulidade de Cláusula Contratual c/c Obrigação de Fazer c/c Reparação por Danos Morais. Relação de consumo. Contratos bancários. Descontos de prestações e empréstimo pessoal diretamente da conta salário. (rectius = conta para depósito de proventos de aposentadoria) da autora. Desconto de valor correspondente a $100 \%$ da pensão da consumidoraaposentada. Prática abusiva. Vulnerabilidade. Hipossuficiência fática do idoso aposentado. Onerosidade excessiva. Inteligência da aplicação conjunta dos arts. 40 I, 51 IV e $§ 1$ IIII CDC. Autorização da consumidora que revela vontade viciada do mais frágil. Lesão. Aplicação conjunta dos arts. 157 e 478 NCC. Falta de alternativa do consumidor. Limite do sacrifício. Superendividamento. Patologia freqüente da moderna sociedade massificada de consumo e de crédito. Agressão à dignidade se os descontos incidem sobre o valor da renda integral do cidadão retirando-lhe a possibilidade de manter sua sobrevivência em padrões de dignidade. Fórmula coativa de cobrança que fere a legalidade. Analogia com a situação prevista no inc. IV do art. 649 CPC que proíbe a penhora de salários. Nulidade parcial na forma do art. 42 CDC e da Lei 10820/03 que fixa o percentual de 30\% do salário como limite do desconto por instituições financeiras. Cláusula contratual que estabelece os descontos que só é nula naquilo que sobejar aos $30 \%$ dos ganhos, limite que garante a subsistência da autora. Danos morais desprovidos com fulcro em entendimento majoritário. Sentença mantida. Desprovimento de ambos os recursos. 
instituição financeira estava descontando o valor correspondente a $100 \%$ da pensão da consumidora-aposentada, prática totalmente abusiva. O Tribunal entendeu que a instituição financeira havia desrespeitado o princípio da vulnerabilidade e que não considerou a hipossuficiência fática da consumidora, causando-Ihe onerosidade excessiva, e mais, a autorização para aquele contrato revelava uma vontade viciada do mais frágil o que the causou o superendividamento, denominado como "patologia frequente da moderna sociedade massificada de consumo e de crédito", e ao final agressão à dignidade já que os descontos incidiam sobre o valor da renda integral retirando-Ihe a possibilidade de manter sua sobrevivência em padrões de dignidade.

O fato é que a estrutura legislativa no Brasil que versa sobre os empréstimos consignados é pequena e o Código de Defesa do Consumidor ainda é omisso, desta forma os Ministérios da Previdência, da Justiça e da Fazenda desenvolveram um Roteiro Técnico com orientações a respeito da concessão do desconto na folha para aposentados e pensionistas com base nas regulamentações contidas nas instruções normativas do Instituto Nacional de Previdência Social - INSS. Como exemplo, cita-se a Instrução Normativa $n^{\circ} 28 / 2008$, na qual, dentre outras previsões, há o estabelecimento de um limite para o valor das prestações, que não pode exceder a $20 \%$ do valor da aposentadoria ou da pensão (artigo 1으, parágrafo 1으, alínea ' $a$ '), bem como para o número de prestações, que não podem exceder a 60 parcelas mensais e sucessivas, conforme dispõe o artigo 13 , inciso I.

Frente a esta realidade e a necessidade imposta pelo Tribunal de Contas do Estado quanto a abertura do processo licitatório de empresa para gerir tais operações, o Governo do Estado de Rondônia chamou para si tal responsabilidade criando a Lei Complementar n.으 622 de 11 de julho de 2011 que instituiu a Comissão Especial de Consignações - CECON.

A nova norma surge também para preencher a lacuna existente no Regime Jurídico do Servidor Público Estadual ${ }^{13}$ que prevê a consignação em folha de pagamento na forma definida em regulamento próprio e não se trata de uma inovação do Estado de Rondônia, haja vista que o regulamento sobre empréstimos consignados tem sido uma preocupação em vários outros Estados, dentre eles, Minas Gerais ${ }^{14}$, Goiás ${ }^{15}$, Amazonas $^{16}$, além do próprio Governo Federal que desde 02 de janeiro de 1950 tem a matéria regulada pela Lei no 1.046.

\footnotetext{
13 Art. 67 da Lei Complementar do Estado de Rondônia n. 68 de 9 de dezembro de 1992.

14 Lei no 19.490 de 13 de janeiro de 2011.
} 
A Lei Complementar n. 622/2011, classifica as consignações em compulsória e facultativa, conceitua no parágrafo 1으 do artigo 1ㅇ a consignação compulsória como 0 desconto incidente sobre a remuneração do servidor, efetuado por força de lei ou mandado judicial, assim compreendido: I - contribuição para a previdência social; II - pensão alimentícia judicial; III - imposto sobre rendimento do trabalho; IV - reposição e indenização ao erário; V - contribuição para sindicato e VI - outros descontos compulsórios instituídos por lei.

Já no parágrafo 20 do artigo supra citado, determina que a consignação facultativa é o desconto incidente sobre a remuneração do servidor, mediante sua autorização prévia e formal e anuência da Administração, nas seguintes modalidades: I - financiamento da casa própria; II seguro de vida; III - contribuição para previdência privada; IV - contribuição para entidades de classe, associações, clubes e cooperativas de consumo ${ }^{17}$ para os servidores estaduais; V - amortização de juros e dívidas; VI - contribuição para plano de saúde; VII aquisição de medicamentos e produtos farmacêuticos; VIII - contribuição para assistência odontológica, ótica e médico-hospitalar e psicológica e IX - financiamento dos estudos, nível superior e técnico profissionalizante mediante convênio com o Estado.

Os artigos 2ㅇ e 3ㅇ da lei estadual denominam como destinatários dos créditos resultantes das consignações os órgãos da administração pública estadual direta e suas autarquias, fundações, empresas públicas e sociedades de economia mista; as associações e clubes criados para atender o servidor público; as entidades de classe representativa; as instituições de crédito, construtores e incorporadores para o caso de aquisição de casa própria; o Programa de Arrendamento Residencial ${ }^{18}$, bem como as entidades de previdência privada e securitárias, instituições financeiras e cooperativas de créditos autorizadas pelo Banco Central e as instituições financeiras que administram cartões de crédito mediante autorização do Banco Central. Quanto a estas, o parágrafo 2o do artigo 3으 da lei n.으 622/2011 limita-as como destinatárias somente para o fim a que se destinam, portanto só poderão ser realizados empréstimos consignados, relativo à contribuição para pecúlio,

15 Lei no 16.898 , de 26 de janeiro de 2010.

16 Decreto 26.954 de 27 de agosto de 2007.

17 O objetivo social de uma cooperativa de consumo é a defesa econômico-social dos seus associados, por meio de ajuda mútua. Conceito extraído do sítio eletrônico <www.pampulha.elias.nom.br> Acessado em: $15 / 03 / 2012$.

18 Lei n.o 10,188 de 12 de fevereiro de 2001. 
seguro de vida, saúde, renda mensal, consumo de alimentos, previdência complementar e amortização de empréstimos e financiamentos.

Neste contexto, importante ressaltar que para os fins de tutela do Código de Defesa do consumidor, os destinatários dos créditos acima serão compreendidos como fornecedores se forem pessoa física ou jurídica, pública ou privada, nacional ou estrangeira ou ente despersonalizado que desenvolva atividade de produção, montagem, criação, construção, transformação, importação, exportação, distribuição ou comercialização de produtos ou prestação de serviços, conforme dispõe o artigo 3ำ do CDC.

E mais, quando se tratar de prestação de serviço de natureza bancária financeira, de crédito e securitária, conforme já se afirmou alhures, observar-se-á a previsão do parágrafo 20 do artigo 2ำ do Código de Defesa do Consumidor que conceitua o serviço como "qualquer atividade fornecida no mercado de consumo, mediante remuneração, inclusive as de natureza bancária, financeira, de crédito e securitária, salvo as decorrentes das relações de caráter trabalhista".

A Lei Complementar n. 622/2011 estipula o prazo máximo destas operações de empréstimos, financiamentos, refinanciamentos e compras de dívida em 60 (sessenta) meses, exceto para as prestações referentes a aquisição de casa própria e amortização de cartão de crédito, cujo limite máximo é de 360 (trezentos e sessenta) meses, conforme previsão do parágrafo 3ำ, artigo 3ㅇ․

Doravante, o artigo 4ำ estabelece a necessidade que os destinatários de crédito se credenciem como consignatários passando pelo crivo da Comissão Geral de Consignação, e anualmente reapresentem documentos comprobatórios de seu credenciamento.

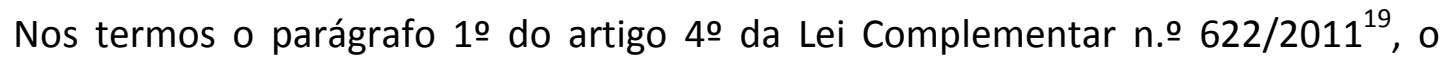
Estado se tornou o intermediário e gestor do processo de consignação de desconto em folha de pagamento dos servidores públicos ativos, inativos, pensionistas e empregados públicos; afastando a gerência de instituições privadas e exercendo o papel de fiscalização do superendividamento do servidor.

19 Art. 4ㅇ, §1으, da Lei Complementar n.o 622/2011: O ato de credenciamento é vinculado aos termos desta Lei Complementar e não configura acordo, formal ou tacito, entre o Estado e o consignatário credenciado, sendo a Administração Estadual exclusivamente a intermediária e gestora do processo de consignação de desconto em folha de pagamento dos servidores ativos, inativos, pensionistas e empregados públicos. 
A Responsabilidade civil na concessão do empréstimo consignado: uma análise do superendividamento do servidor público no estado de Rondônia

Com efeito, as somas das consignações compulsórias e facultativas não poderão ultrapassar o limite de $70 \%$ da remuneração mensal do servidor e sobre esta se excluem as vantagens de salário-família, diárias, ajuda de custo, gratificação natalina, adicional de horário noturno, $1 / 3$ constitucional pelo usufruto de férias, o serviço extraordinário, sobreaviso ou hora plantão bem como a substituição de cargo em comissão ou função de confiança, prêmio de assiduidade e importâncias pretéritas, conforme artigo 6으, parágrafo 1ㅇ da Lei Complementar n.ㅇ 622/2011.

Considerando que a soma das consignações ultrapasse o limite estabelecido pela Lei, os descontos serão suspensos até haver o enquadramento do referido limite, e quanto as consignações facultativas, serão descontadas as de menores níveis de prioridade, segundo o que dispõe o artigo 6으, parágrafo $2{ }^{\circ}$, incisos I, II e III, IV e V, prevalecendo-se também o critério de antiguidade ${ }^{20}$.

Conforme já mencionado, as retenções quase que integral dos salários, destinados a empréstimos consignados é tema recorrente nos tribunais e no Superior Tribunal de Justiça. Decisões sobre o empréstimo consignado formaram jurisprudência que busca proteger os trabalhadores, sem desrespeitar os contratos.

A este respeito, em fevereiro de 2011, a 3a turma do STJ decidiu no Recurso Especial no 1.186 .965 que a soma mensal das prestações referentes às consignações facultativas ou voluntárias, como empréstimos e financiamentos, não pode ultrapassar o limite de $30 \%$ dos vencimentos do trabalhador. O relator, Ministro Massami Uyeda, levou em consideração a natureza alimentar do salário e o princípio da razoabilidade, para atingir o equilíbrio entre os objetivos do contrato firmado e a dignidade da pessoa.

Neste contexto e com base nos princípios da boa-fé e do equilíbrio (artigo 4ํㅡ, inciso III, CDC) e da vulnerabilidade do consumidor (artigo 4으, inciso I) advindo da necessidade de aplicar o princípio constitucional da isonomia, a Lei Complementar n. 622/2011 prevê ainda que a consignação facultativa pode ser cancelada a pedido formal do consignado bem como por conveniência e oportunidade a juízo da administração (artigo 7ํ, incisos V e VI).

20 Art. $6^{\circ}$. A soma das consignações compulsórias e facultativas não excederá o limite de $70 \%$ (setenta por cento) da remuneração mensal do servidor, respeitando o limite de 30\% (trinta por cento) para as facultativas. $\S 1$ ㅇ. Não serão computadas na remuneração referida neste artigo as seguintes vantagens pecuniárias: I - salário-família; II - diárias; III - ajuda de custo; IV - gratificação natalina; V - horário noturno; VI - 1/3 (um terço) constitucional pelo usufruto de f érias; VII - serviço extraordinário, sobreaviso ou hora plantão; VIII - substituição de cargo em comissão ou função de confiança; IX - prêmio assiduidade; e X importâncias pretéritas. Lei no 622/2011. 
A Lei estadual assegura ainda que independente de contrato ou convênio entre o consignatário e o consignado, o pedido de cancelamento da consignação por parte do consignado deverá ser atendido imediatamente com a cessação do desconto na folha de pagamento em que foi formalizado, é o que prescreve a redação do artigo 7으, parágrafo 1‥

Ademais, qualquer alteração ou exclusão de produto ou serviço informado no ato do credenciamento pelo consignatário deverá ser analisada e aprovada pela Comissão Especial de Consignações (artigo 8으, caput), no tocante a isto, o parágrafo 2 을 do artigo 8 응 dispõe que se o consignatário intermediar serviços e produtos de terceiros responderá solidariamente e havendo a constatação de fraude, simulação, dolo, conluio ou culpa que caracterize a utilização ilegal da folha de pagamento dos servidores importará na imediata suspensão da consignação e desativação temporária ou definitiva do consignatário.

Além do mais, a Lei Complementar das consignações condicionou o descredenciamento das entidades consignatárias ao atendimento das exigências desta lei e dentre as proibições, consideradas como condutas irregulares, previstas no artigo 10, encontram-se alguns dispositivos já elencados no Código de Defesa do Consumidor, dentre eles, a prática abusiva estabelecida no artigo 35, inciso I da Lei 8.078/90, chamada de venda casada $^{21}$, a cobrança de quantia indevida ${ }^{22}$, a qual pela lei do consumidor enseja na repetição do indébito ${ }^{23} \mathrm{e}$ a publicidade enganosa ${ }^{24}$. Portanto, o desrespeito às normas regulamentadoras da relação de consumo ensejará a responsabilização de eventual dano ao consumidor.

\section{A responsabilidade civil das instituições financeiras na concessão do empréstimo consignado}

Conforme verificamos anteriormente o Código de Defesa do Consumidor deixa claro a preocupação em tutelar a parte vulnerável na relação de consumo. Dessa forma, a concessão do empréstimo consignado em folha de pagamento deve respeitar as normas atinentes a matéria, para dar origem a um negócio jurídico transparente e legal. Entretanto,

\footnotetext{
Art. 10, §1으, II, Lei Complementar 622, de 11 de julho de 2011.

Art.10, §1으, I, Lei Complementar 622, de 11 de julho de 2011.

Art. 42, parágrafo único, CDC.

Art. 10 §1으, III, Lei Complementar 622, de 11 de julho de 2011.
} 
podem ocorrer práticas que não observam estas leis, resultante na violação aos direitos do consumidor, nascendo, assim, o direito à reparação pelos danos causados.

Na relação de consumo, conforme estabelece o Código de Defesa do Consumidor, o causador do dano deve repará-lo, independente de culpa, ou seja, da existência do dano efetivo ao ofendido, conforme dispõe o artigo $12 .{ }^{25}$ Deste modo, o que prevalece no Código quanto à relação de consumo é a responsabilidade civil objetiva do fornecedor, já que o consumidor é a parte mais vulnerável da relação de consumo. Não só pela dificuldade em demonstrar a culpa do fornecedor, mas também no regime de produção em série (massa), o fornecedor não pode ser considerado, por via de regra, negligente, imprudente ou imperito.

A natureza jurídica da responsabilidade encontra-se disciplinada pelo artigo 6ㅇ, inciso VI, como um direito básico do consumidor, ao assegurar a efetiva prevenção e reparação dos direitos patrimoniais, morais, individuais e coletivos.

A responsabilidade objetiva é oriunda do risco integral de sua atividade econômica. A responsabilidade de indenizar nasce do nexo de causalidade existente entre o consumidor (lesado), o produto/serviço e o dano efetivamente ocorrente. Conforme afirma Melo (2008, p. 94), "a teoria do risco foi desenvolvida a partir da constatação de que a responsabilidade fundada na culpa se mostrava insuficiente para que o lesado obtivesse a plena satisfação de seus prejuízos".

Nesse mesmo sentido Carlos Roberto Gonçalves (2012, p. 82) afirma que "toda pessoa que exerce alguma atividade cria o risco de dano para terceiros. E deve ser obrigada a repará-lo, ainda que sua conduta seja isenta de culpa". Portanto, as instituições financeiras estão inseridas entre estes fornecedores, pois assumem o risco ao disponibilizarem serviços e produtos no mercado de consumo.

A responsabilidade civil na prestação de serviço ocorrerá quando houver vícios de consumo do produto ou serviço ou fato/defeito/acidentes de consumo do produto ou serviço. Pelo vício entende-se como uma falha intrínseca na qualidade ou quantidade que afeta a funcionalidade ou o valor do produto ou serviço. Pode ser aparente, sendo observado durante o uso/consumo, ou oculto quando verificado futuramente depois de

25 Art. 12. O fabricante, o produtor, o construtor, nacional ou estrangeiro, e o importador, respondem, independentemente da existência de culpa, pela reparação dos danos causados aos consumidores por defeitos decorrentes de projeto, fabricação, construção, montagem, fórmulas, manipulação, apresentação ou acondicionamento de seus produtos, bem como por informações insuficientes ou inadequadas sobre sua utilização e riscos. CDC. 
muito tempo de uso pelo consumidor. Quanto ao fato do produto, o defeito vai além do produto ou do serviço para atingir o consumidor no seu patrimônio jurídico mais amplo (seja moral, material, estético ou de imagem). Portanto, acidente de consumo só na hipótese de defeito ${ }^{26}$.

O Código de Defesa do Consumidor trata da responsabilidade pelos vícios de qualidade do produto no artigo $18^{27}$, o vício de quantidade do produto no artigo $19^{28}$ e os vícios dos serviços no artigo $20^{29}$. Em relação ao fato do produto está disposta no art. $12^{30} \mathrm{e}$ artigo $13^{31}$, já em relação ao fato do serviço está prevista no artigo $14^{32}$ do CDC.

Logo, responderá a instituição financeira pela violação aos direitos ao consumidor/servidor público na concessão do empréstimo consignado em folha de pagamento objetivamente, pois aos disponibilizar tais serviços/produtos no mercado de consumo, assume os riscos que da atividade advém.

26 João Batista de Almeida afirma que "enquanto a primeira há a potencialidade danosa, na segunda esta inexiste, verificando-se apenas anomalias que afetam a funcionalidade do produto e do serviço. Estes, na primeira, são afetados por defeitos que trazem riscos à saúde e segurança do consumidor; na segunda, são observados apenas vícios de qualidade e quantidade, afetando o funcionamento ou o valor da coisa. A responsabilidade pelo fato objetiva tutelar a integridade físico-psíquica, ensejando ampla reparação de danos; a responsabilidade por vícios busca proteger a esfera econômica, ensejando tão-somente o ressarcimento segundo as alternativas previstas na lei de proteção: substituição da peça viciada, substituição do produto por outro, restituição da quantia paga ou abatimento do preço (art. 18, caput e $\S$ 1ㅇ, I a III)" ALMEIDA, João Batista de. A proteção jurídica do consumidor, 3. Ed. Rev., Atual. e Ampl. São Paulo: Saraiva, 2002, p. 92.

27 Art. 18. Os fornecedores de produtos de consumo duráveis ou não duráveis respondem solidariamente pelos vícios de qualidade ou quantidade que os tornem impróprios ou inadequados ao consumo a que se destinam ou lhes diminuam o valor, assim como por aqueles decorrentes da disparidade, com as indicações constantes do recipiente, da embalagem, rotulagem ou mensagem publicitária, respeitadas as variações decorrentes de sua natureza, podendo o consumidor exigir a substituição das partes viciadas. CDC.

28 Art. 19. Os fornecedores respondem solidariamente pelos vícios de quantidade do produto sempre que, respeitadas as variações decorrentes de sua natureza, seu conteúdo líquido for inferior às indicações constantes do recipiente, da embalagem, rotulagem ou de mensagem publicitária, podendo o consumidor exigir, alternativamente e à sua escolha. CDC.

29 Art. 20. Os fornecedores de serviços responde pelos vícios de qualidade que os tornem impróprios ao consumo ou thes diminuem o valor, assim como por aqueles decorrentes da siparidade com indicações constantes da oferta ou mensagem publicitária, podendo o consumidor exigir, alternativamente à sua livre escolha: (...). CDC.

30 Art. 12. O fabricante, o produtor, o construtor, nacional ou estrangeiro, e o importador respondem, independentemente da existência de culpa, pela reparação dos danos causados aos consumidores por defeitos decorrentes de projeto, fabricação, construção, montagem, fórmulas, manipulação, apresentação ou acondicionamento de seus produtos, bem como por informações insuficientes ou inadequadas sobre sua utilização e riscos. CDC.

31 Art. 13. O comerciante é igualmente responsável, nos termos do artigo anterior, quando: (...). CDC.

32 Art. 14. O fornecedor de serviços responde, independentemente da existência de culpa, pela reparação dos danos causados aos consumidores por defeitos relativos à prestação dos serviços, bem como por informações insuficientes ou inadequadas sobre sua fruição e riscos. CDC. 
A Responsabilidade civil na concessão do empréstimo consignado: uma análise do superendividamento do servidor público no estado de Rondônia

Geralmente aplicar-se-á às relações bancárias a responsabilidade pelo fato do serviço prestado, pois ao concederem o empréstimo as instituições financeiras ferem a segurança do consumidor/servidor público, pois a falta de regularidade no serviço prestado surge quando a instituição financeira coloca o consumidor em situação de desequilíbrio na relação contratual.

Assim, rompe com a boa-fé objetiva e a confiança dispensada pelo consumidor à instituição quando da aceitação do serviço. Por exemplo, quando a instituição financeira fornece um valor muito maior ao consumidor, que vê o seu salário mensal $100 \%$ comprometido, conforme ressaltamos no capítulo anterior. Nesse caso, atinge o consumidor tanto no seu aspecto material como moral. Outro exemplo que podemos citar em relação à responsabilidade pelo fato do serviço, é quando a instituição financeira realiza descontos indevidos em folha de pagamento. Nesse sentido, cabe fazermos referência a decisão dos Embargos Infringentes e da Apelação Cível, emanadas pelo Tribunal de Justiça do Estado de Rondônia, com o seguinte teor:

EMBARGOS INFRINGENTES. INSTITUIÇÃO FINANCEIRA. DESCONTO INDEVIDO EM FOLHA DE PAGAMENTO. DANOS MORAIS. A instituição financeira é responsável pela regularidade do contrato relativo a empréstimo, cujo débito é consignado em folha de pagamento mensal. Se não adota as medidas no sentido de comunicar indevidos descontos, responde civilmente pelos danos causados, materiais e morais. $^{33}$

APELAÇÃO CÍVEL. DANOS MORAIS. EMPRÉSTIMO CONSIGNADO NÃO CONTRATADO. AUSÊNCIA DE CAUTELA DO AGENTE FINANCEIRO. DESCONTO INDEVIDO DE PARCELAS. CONSTRANGIMENTOS DEMONSTRADOS. DEVER DE INDENIZAR. Constatada a negligência de agente financeiro em efetuar descontos na folha de pagamento por empréstimo não contratado, situação que acarretou no comprometimento da renda do apelado, configura-se o dano moral, sendo necessária sua reparação. Provimento negado, unânime. ${ }^{34}$

Importante frisarmos que com o surgimento do Código de Defesa do Consumidor, foi rompido com a tradição do direito privado. A Lei 8.078/90 trouxe garantias e princípios já

33 TRIBUNAL DE JUSTIÇA DO ESTADO DE RONDÔNIA. Acórdão. Vistos, relatados e discutidos estes autos, acordam os Desembargadores das Câmaras Cíveis Reunidas do Tribunal de Justiça do Estado de Rondônia, na conformidade da ata de julgamentos e das notas taquigráficas em, por unanimidade, dar provimento aos embargos nos termos do voto do relator. Porto Velho, 4 de fevereiro de 2011. Desembargador Marcos Alaor Diniz Grangeia (Presidente). Autos n. 0014425-97.2010.8.22.0000. Embargante: Antônia Serafim Silva. Embargado: Banco Cruzeiro do Sul S/A.

34 TRIBUNAL DE JUSTIÇA DO ESTADO DE RONDÔNIA. 1ạ Câmara Cível do Tribunal de Justiça do Estado de Rondônia, autos n. 0004307-59.2010.8.22.0001 Apelante: Banco Cruzeiro do Sul S/A, Apelado: Boorton Mendonça Postigo. Porto Velho, 14 de fevereiro de 2012). 
consagrados pela nossa Constituição Federal, bem como rompeu de vez com o princípio da pacta sunt servanda ao reconhecer que em matéria de relação de consumo prevalece a regra da oferta, que vincula ${ }^{35}$, e não a regra das cláusulas pactuadas pelas partes, em razão de que na maioria das vezes os contratos são elaborados unilateralmente (contrato de adesão) por uma das partes (NUNES, 2011, p. 654-655).

Por conseguinte, esse princípio da boa-fé objetiva foi consagrado explicitamente no Código de Defesa do Consumidor, e disciplina o respeito à boa-fé dos contratantes, antes, durante e depois do contrato, conforme artigo 4 , inciso $1 I^{36}$ e artigo $51^{37}$ do CDC.

A harmonização nasce fundada na boa-fé ${ }^{38}$ e no equilíbrio. Podemos considerar o princípio da boa-fé como um dos ditames constitucionais, sendo topos fundamentais dos operadores do direito, ou seja, espécie de pré-condição abstrata de uma relação ideal (justa). Essa proteção contratual no contrato de consumo decorre também da vulnerabilidade do consumidor (artigo 4으, inciso I), que decorre da aplicação do princípio constitucional da isonomia (artigo 5ㅇ, caput, da Constituição Federal ${ }^{39}$ ), os quais garantem o direito de modificação das cláusulas contratuais. E, quando ocorrer o dano, deve haver a reparação por parte de quem ocasionou.

Neste sentido, não restam dúvidas quanto à existência de responsabilização das Instituições Financeiras na concessão do empréstimo consignado em folha de pagamento pelos tribunais brasileiros. Assim, cabe citarmos decisão do Tribunal de Justiça do Estado do

35 Art. 30. Toda informação ou publicidade, suficientemente precisa, veicula por qualquer forma ou meio de comunicação com relação a produtos e serviços oferecidos ou apresentados, obrigada o fornecedor que a fizer veicular ou dela se utilizar e integra o contrato que vier a ser celebrado. CDC.

${ }^{36}$ Art. 40, III. A Política Nacional das Relações de Consumo tem por objetivo o atendimento das necessidades dos consumidores, o respeito à sua dignidade, saúde e segurança, a proteção de seus interesses econômicos, a melhoria de sua qualidade de vida, bem como a transparência e harmonia das relações de consumo, atendidos os seguintes princípios: (...), III - harmonização dos interesses dos participantes das relações de consumo e compatibilização da proteção do consumidor com a necessidade de desenvolvimento econômico e tecnológico, de modo a viabilizar os princípios nos quais se funda a ordem econômica (art. 170 da Constituição Federal), sempre com base na boa-fé e equilíbrio das relações de consumo. CDC.

37 Art. 51. São nulas de pleno direito, entre outras, as clausulas contratuais relativas ao fornecimento de produtos e serviços que: (...). CDC.

38 A boa- fé objetiva é a que está presente no CDC (regra de conduta), dever das partes de agir com lealdade, honestidade, a fim de estabelecer o equilíbrio. A boa-fé subjetiva é aquela diz respeito à ignorância de uma pessoa acerca de um fato.

39 Art. 5o, caput. Todos são iguais perante a lei, sem distinção de qualquer natureza, garantindo-se aos brasileiros e aos estrangeiros residentes no País, a inviolabilidade do direito à vida, à liberdade, à igualdade, à segurança e a propriedade, nos termos seguintes: (...). CF. 
Rio Grande do Sul, o qual exarou decisão em Recurso de Apelação n. 70031132301, com o seguinte teor:

RESPONSABILIDADE CIVIL. CONCESSÃO DE EMPRÉSTIMO BANCÁRIO CONSIGNADO, MEDIANTE APRESENTAÇÃO DE DOCUMENTOS DO AUTOR. FRAUDE NA CONTRATAÇÃO. RESPONSABILIDADE DO BANCO. CONFERÊNCIA DOS DADOS. AUSÊNCIA DE CAUTELA PELA INSTITUIÇÃO FINANCEIRA. CULPA EVIDENCIADA. DANOS MORAIS CARACTERIZADOS. COMPENSAÇÃO. MANUTENÇÃO. DEVOLUÇÃO DOS VALORES EM DOBRO. ${ }^{40}$

Nesse caso torna-se mais grave ainda em razão de inexistir relação contratual entre as partes. Mesmo assim, tem pertinência o disposto no artigo 17 da Lei $n$.ㅇ 8.078/90, segundo o qual se equiparam aos consumidores todas as vítimas do evento. Logo, em sendo a parte, consumidor por equiparação, a responsabilidade da financeira é objetiva, incidindo, in casu, o estabelecido no artigo 14 do CDC, e ainda, o banco ao conceder empréstimo com desconto em folha de pagamento deveria, indispensavelmente, realizar a conferência da documentação apresentada pelo cliente, que se utilizou de documentos adulterados. Essa atitude da instituição financeira agride a dignidade pessoal do consumidor, e por ora, o princípio da dignidade da pessoa humana, conforme preceitua o artigo $1 \stackrel{0}{ }$, inciso III, da Constituição Federal de 1988. Funciona como princípio maior para a interpretação de todos os direitos e garantias fundamentais, e para proteger as pessoas de qualquer lesão aos direitos inerentes a pessoa humana.

Ainda existem dúvidas, portanto, se há responsabilização do Estado que autoriza o desconto em folha de pagamento. Nesse contexto, a 2a turma do STJ decidiu que quando o desconto é na folha de pagamento do servidor público, entende que é cabível acionar o ente estatal para responder à ação. Foi o que decidiram os ministros no julgamento do recurso especial n.o 1.113.576:

PROCESSUAL CIVIL E ADMINISTRATIVO - RECURSO ESPECIAL - PENSIONISTA DE MILITAR - CONTRATO DE EMPRÉSTIMO - LIMITE DE CONSIGNAÇÃO EM FOLHA DEVER DE FISCALIZAR DESCONTOS EFETUADOS EM CONTRACHEQUES LEGITIMIDADE PASSIVA DA UNIÃO. ${ }^{41}$

40 Apelo improvido e parcialmente provido o recurso adesivo.

41 SUPERIOR TRIBUNAL DE JUSTIÇA. Recurso Especial № 1.113.576 - RJ (2009/0051213-7). Foi reconhecida a legitimidade passiva da União, na medida em que configurada sua responsabilidade pela inclusão de descontos em folha de pagamento de pensionistas de militares, visto que é o ente público que efetua o pagamento de seus salários. 3. Recurso especial não provido. 
Com efeito, esta decisão deixa clara a proteção ao consumidor, pois não obstante a concordância do mutuário na celebração do contrato de empréstimo com a instituição financeira cabe a União fiscalizar os descontos em folha, como a cobrança de parcela de empréstimo bancário contraído.

Portanto, tanto em âmbito de competência /federal, a responsabilidade será da União, como em âmbito de competência estadual, em que a responsabilidade é do Estado.

A autorização pelos descontos em folha de pagamento tem recebido cada vez mais responsabilidade por esta gestão. O poder judiciário tem condenado a União ou o Estado (conforme o seu âmbito de competência) a responsabilidade subjetiva, mediante a conjugação concomitante de três elementos - dano, negligência administrativa e nexo de causalidade entre o evento danoso e o comportamento ilícito do poder público ${ }^{42}$.

Dessa forma, demonstra que foi aplicada, de forma excepcional, a responsabilidade subjetiva, pois conforme já referido anteriormente, a regra nas relações de consumo é a responsabilidade objetiva. Todavia, conforme o caso citado ficou demonstrado a culpa da União ${ }^{43}$ ao permitir os descontos efetuados nos contracheques do servidor, fundamentando que cabia a União fiscalizar estes descontos.

Mas cabe ressaltarmos novamente que a regra é a responsabilização objetiva do Estado, ficando ainda mais caracterizado quando da entrada em vigor da Lei Complementar n.o 622/2011 do Estado de Rondônia, conforme explicada no capítulo anterior. Restou comprovado que esta veio ainda mais regulamentar e proteger as relações de consumo, quando afirma no seu artigo 4으, parágrafo 1으, que o Estado se tornou o intermediário e gestor do processo de consignação de desconto em folha de pagamento. Assim, afastando a

42 PROCESSUAL CIVIL E ADMINISTRATIVO. RESPONSABILIDADE CIVIL DO ESTADO. ATO OMISSIVO DA ADMINISTRAÇÃO. INSS. CONDENAÇÃO EM DANOS MORAIS. CABIMENTO. QUANTUM DEBEATUR. REDUÇÃO. REEXAME DO CONJUNTO FÁTICO-PROBATÓRIO. INVIABILIDADE. SÚMULA 7/STJ. 1. Hipótese em que o Tribunal a quo, soberano no exame da prova, julgou que são ilegais os descontos nos proventos de aposentadoria da autora, porquanto inexistente o acordo de empréstimo consignado, e que a autarquia previdenciária agiu com desídia ao averbar contrato falso. 2. A jurisprudência do STJ é pacífica no sentido de que, caracterizada a responsabilidade subjetiva do Estado, mediante a conjugação concomitante de três elementos - dano, negligência administrativa e nexo de causalidade entre o evento danoso e o comportamento ilícito do Poder Público -, é inafastável o direito do autor à indenização ou reparação civil dos prejuízos suportados. 3. O valor dos danos morais, fixado em $\mathrm{R} \$ 5.000,00$ (cinco mil reais), não se mostra exorbitante ou irrisório. Portanto, modificar o quantum debeatur implicaria, in casu, reexame da matéria fático-probatória, obstado pela Súmula 7/STJ. 4. Recurso Especial não provido.

43 No caso foi a União, mas não podemos deixar de fazer referência que a União é um dos entes federativos, conforme dispõe o Art. 1 o e Art. 18 da Constituição Federal. Nesse contexto, conforme a repartição de competência a decisão está se referindo a União, mas poderia ser o Estado, ou Município ou o Distrito Federal, pois todos são entes da nossa federação, agindo conforme suas respectivas competências. 
gerência de instituições privadas e exercendo o papel de fiscalização do superendividamento do servidor.

E, como medida de proteção ao consumidor, bem como para evitar o superendividamento do servidor, o Tribunal de Justiça do Estado de Rondônia vem concedendo tutela antecipada a fim de limitar ao teto de $30 \%$ dos vencimentos do contratante:

AGRAVO. ANTECIPAÇÃO DE TUTELA. CONTRATO DE EMPRÉSTIMO CONSIGNADO. PARCELAS EM VALOR ELEVADO. LIMITAÇÃO AO TETO DE 30\% DOS VENCIMENTOS DO CONTRATANTE. REVERSIBILIDADE DA MEDIDA. POSSIBILIDADE. REFORMA DA DECISÃO AGRAVADA. É possível a antecipação de tutela a fim de reduzir o percentual de descontos consignados em vencimentos mensais para patamar que adeque ao teto de $30 \%$ previsto nas normas regulamentadoras, até que se julgue o mérito da ação principal de revisão de contratos, a fim de preservar a subsistência do devedor. ${ }^{44}$

A única exceção ao sistema de responsabilidade civil objetiva do Código Civil do Consumidor é a responsabilidade civil do profissional liberal, em razão do que prevê o art. 14, parágrafo 4ํㅡ, do $\operatorname{CDC}^{45}$. É o caso dos médicos, advogados, dentistas, engenheiros, entre outros que estejam no desempenho de sua atividade como profissionais liberais propriamente ditos. Nesse caso, deverá haver a verificação da sua conduta subjetiva, o dolo ou a culpa - negligência, imprudência e imperícia, em que a prática de qualquer ato ou conduta-meio, comprometeu o resultado do seu trabalho. Assim, se presente qualquer destes componentes que cooperam para a sua culpa, como tal deverá responder pelos danos causados ao consumidor.

Também gera responsabilização por parte da instituição financeira quando verificado que o consumidor nunca recebeu o crédito, e mesmo assim ocorrem os descontos das prestações. E conforme decisão do Tribunal de Rondônia independe de prova, porque a ofensa decorre da própria conduta ilícita do Banco, comprovando a sua responsabilidade objetiva:

44 TRIBUNAL DO ESTADO DE RONDÔNIA. Acórdão. Vistos, relatados e discutidos estes autos, acordam os Desembargadores da 2a Câmara Cível do Tribunal de Justiça do Estado de Rondônia, na conformidade da ata de julgamentos e das notas taquigráficas em, por unanimidade, dar provimento ao recurso nos termos do voto do relator. Porto Velho, 28 de julho de 2010. Desembargador Marcos Alaor Diniz Grangeia (presidente). Autos n. 0003616-14.2011.8.22.0000. Agravante: José Wank Gomes de Morais. Agravados: HSBC Bank Brasil S.A - Banco Múltiplo, Banco Daycoval S.A. e Banco Cruzeiro do Sul S.A.

45 A responsabilidade pessoal dos profissionais liberais será apurada mediante a verificação de culpa. 
INDENIZAÇÃO. CONTRATO DE EMPRÉSTIMO CONSIGNADO. DANO MORAL. PROVA. DESNECESSIDADE. FRAUDE. PRINCÍPIO DA RAZOABILIDADE. QUANTUM INDENIZATÓRIO. MAJORAÇÃO.POSSIBILIDADE. É indevida a cobrança de prestações mensais decorrente de empréstimo consignado, quando verificado que o consumidor nunca recebeu o crédito da instituição financeira. Nesse caso, o dano moral independe de prova, mormente porque a ofensa decorre da própria conduta ilícita do banco. ${ }^{46}$

EMPRÉSTIMO CONSIGNADO. NÃO CONTRATAÇÃO. DESCONTO INDEVIDO. BENEFÍCIO PREVIDENCIÁRIO. RESTITUIÇÃO EM DOBRO. DANOS MORAIS. VALOR. Constatada a não contratação de empréstimo consignado e ocorrendo desconto indevido e significativo em benefício previdenciário, impõe-se a devolução em dobro do que fora descontado tanto quanto o reconhecimento do dano moral. ${ }^{47}$

O ponto fundamental do respeito às normas atinentes à relação de consumo para não gerar responsabilização, consiste no requisito de obrigatoriedade de segurança para os produtos que ingressam no mercado de consumo. Não podemos deixar de citar, nesse contexto, que entre os direitos básicos do consumidor, encontra-se o art. 6으, que disciplina “a proteção da vida, saúde e segurança consta os riscos provocados por práticas no fornecimento de produtos e serviços considerados nocivos". Analisando os artigos $80^{48}$ e seguintes do $C D C$, sob o aspecto de cunho preventivo da norma, têm caráter cogente e coercitivo dentro da sistemática legal e proteção ao consumidor, em decorrência de serem questões afetas à saúde e segurança entre as mais relevantes suscitadas pela disciplina de proteção do consumidor.

A proteção do direito à vida pode ser interpretada em âmbito constitucional ${ }^{49}$, como

46 TRIBUNLA DE JUSTIÇA DO ESTADO DE RONDÔNIA. Acórdão. Vistos, relatados e discutidos estes autos, acordam os Desembargadores da 1a Câmara Cível do Tribunal de Justiça do Estado de Rondônia, na conformidade da ata de julgamentos e das notas taquigráficas em, por unanimidade, dar parcial provimento ao recurso do Banco Schahim s/a e dar provimento ao de Miltom Teodoro nos termos do voto o relator. Porto Velho, 28 de junho de 2011. Desembargador(a) Sansão Saldanha (presidente). Autos $\mathrm{n}$. 0004647-88.2010.8.22.0005. Apte/Apda: Maria Alves Pessoa. Apdo/Apte : Banco Bonsucesso S/A.

47 TRIBUNAL DE JUSTIÇA DO ESTADO DE RONDÔNIA. Acórdão. Vistos, relatados e discutidos estes autos, acordam os Desembargadores da 1a Câmara Cível do Tribunal de Justiça do Estado de Rondônia, na conformidade da ata de julgamentos e das notas taquigráficas em, por unanimidade, dar provimento ao recurso nos termos do voto do relator. Porto Velho, 28 de junho de 2011. Desembargador(a) Sansão Saldanha (presidente). Autos n.o 0000556-61.2010.8.22.0002. Apelante: José Eugênio. Apelado: Banco BMG S/A.

48 Os produtos e serviços colocados no mercado de consumo não acarretarão riscos à saúde ou segurança do consumidor, exceto os considerados normais e previsíveis em decorrência de sua natureza e fruição, obrigando-se os fornecedores, em qualquer hipótese, a dar as informações necessárias e adequadas a seu respeito. Parágrafo único. (...). CDC.

49 O direito à vida está consagrado no art. 5o, caput, CF, é o mais importante de todos os direitos. Seu significado é amplo, porque nele se conecta com outros, a exemplo dos direitos à liberdade, à igualdade, à dignidade, à segurança, à propriedade, à alimentação, ao vestuário, ao lazer, à educação, à saúde, à 
a inclusão da proteção da saúde e segurança dos consumidores, bem como comprova o dever do Estado em estabelecer a fiscalização eficaz da responsabilidade civil dos fornecedores pelos danos causados por seus produtos/serviços aos consumidores.

Com efeito, como o Código de Defesa do Consumidor assume como regime jurídico a responsabilidade civil objetiva pelos danos causados, isso significa dizer que a simples existência da atividade econômica no mercado, exercida pelo fornecedor/instituição financeira, já o incumbe do dever de reparar o dano causado por esta atividade. Exceto, nos casos identificados pelo Código de Defesa do Consumidor como excludentes de responsabilidade, conforme artigo 12 , parágrafo 3 으, as hipóteses em que o fabricante, 0 construtor, o produtor ou importador só não será responsabilizados quando provarem que não colocaram o produto no mercado, ou que, embora hajam colocado o produto no mercado, não existe o defeito mencionado, ou ainda, quando haja culpa exclusiva do consumidor ou terceiro.

A excludente da "culpa exclusiva de consumidor ou de terceiro" merece alguns reparos. Pois bem, não há de trazer para o sistema da responsabilidade objetiva a natureza subjetiva, embora o inciso tenha referido culpa exclusiva do consumidor ou de terceiro. 0 legislador não propôs um sistema misto de responsabilidade civil, o que não seria admitido, tendo somente vislumbrado a hipótese, a bem do equilíbrio da relação jurídico-contratual, de poder o consumidor, ou quem quer que seja estranho à relação, adotar práticas que comprometam a segurança esperada do serviço, respeitados todos os princípios e direitos básicos. Exemplo que podemos citar é o tratado pelo presente trabalho, ou seja, o superendividamento do consumidor, o qual não respeita a sua capacidade financeira de contrair empréstimos. _Nesse caso, se o consumidor der margem ao comprometimento de seu rendimento mensal, ensejará a excludente da responsabilidade civil, deixando o fornecedor de responder pelo que experimentou o consumidor como dano decorrente da relação jurídica de consumo.

Portanto, a ausência de atendimento às normas regulamentadores de proteção da relação de consumo no momento da concessão do empréstimo consignado em folha de pagamento, ensejará a responsabilidade civil objetiva das Instituições Financeiras.

habitação, à cidadania, aos valores sociais do trabalho e da livre iniciativa. BULOS, Uadi Lammêgo. Curso de direito constitucional. 6 ed. Ver. Atual. São Paulo: Saraiva, 2011, p. 532-539. 


\section{Conclusão}

Evidente, portanto, a forte tendência protecionista do Estado de Rondônia, contudo, a responsabilidade sobre a liberação do crédito consignado, seus limites e controle ainda é um problema, já que inexiste tutela legal destinada ao tratamento das situações de superendividamento no Brasil, razão pela qual deve haver o respeito a Lei n. 622/2011 e aos princípios e direitos básicos elencados pelo Código de Defesa do Consumidor.

Entretanto, não restaram dúvidas quanto à aplicabilidade do Código de Defesa do Consumidor nas relações entre consumidores e instituições financeiras, especialmente, quando da concessão do empréstimo consignado, o qual se enquadra como uma prestação de serviço de natureza financeira.

A regulamentação e a entrada em vigor da Lei Complementar n.ํ 622/2011 no Estado de Rondônia trouxe grandes avanços para a matéria. Podemos citar dois aspectos importantes: o primeiro, visto como a tentativa de frear o superendividamento dos consumidores/servidores ao verificarem o comprometimento da sua renda mensal, e o segundo, um controle maior na disponibilização pelas instituições financeiras no momento da concessão e execução do empréstimo consignado, atentando-se se o servidor preenche ou não os requisitos objetivos que autorizam a liberação do empréstimo.

Ademais, para que se concretize a prestação de serviço, a instituição financeira deverá passar pelo processo de aprovação realizado pela Comissão Geral de Consignação CECON para que ocorra a liberação do empréstimo, além de, anualmente, reapresentar documentos comprobatórios de seu credenciamento, caracterizando um controle maior sobre essa relação de consumo.

E, caso violem algum dos princípios ou direitos básicos do consumidor, devem ser responsabilizadas objetivamente, independentemente da existência de culpa. Isto resulta do reconhecimento da vulnerabilidade do consumidor e na obrigatoriedade de segurança para a concessão do empréstimo consignado ao servidor, pois a falta de regularidade no serviço prestado surge quando a instituição financeira coloca o consumidor em situação de desequilíbrio na relação contratual.

Quanto ao Estado, como o intermediário e gestor do processo de consignação de desconto em folha de pagamento dos servidores públicos, deverá ser responsabilizado objetivamente caso não respeite às normas consumeristas. 


\section{Referências}

AMAZONAS. Decreto 26.954 de 27 de agosto de 2007. dispõe sobre consignações em folha de pagamento de servidores dos órgãos da Administração Direta, Autárquica e Fundacional do Estado do Amazonas.

BRASIL. Constituição Federal Brasileira de 1988. Disposições Constitucionais Transitórias.

BRASIL. Lei $\mathrm{n} .08078$ de 11 de setembro de 1990. Estabelece o Código de Defesa do Consumidor.

DOCLUS. Miguel. Aspectos da Filosofia Moral e Política de Kant. 2002. Disponível em: <http://www.consciencia.org/2002/05> Acesso em: 08 mar. 2012.

GOIAS. Lei no 16.898, de 26 de janeiro de 2010. Dispõe sobre as consignações em folha de pagamento dos servidores e militares, ativos e inativos, e pensionistas do Poder Executivo Estadual.

GONÇALVES, Carlos Roberto. Direito Civil Brasileiro. 10. ed. São Paulo: Saraiva, 2012. v. 1. MINAS GERAIS. Lei no 19.490 de 13 de janeiro de 2011. Dispõe sobre consignação em folha de pagamento de servidor público Ativo ou inativo e de pensionista do estado e dá outras providências.

NUNES, Luiz Antônio Rizzatto. Comentários ao Código de Defesa do Consumidor. 3. ed. São Paulo: Saraiva, 2007.

NUNES. Luiz Antônio Rizzatto. Curso de Direito do Consumidor. 6. ed. São Paulo: Saraiva, 2011.

RONDÔNIA. Lei Complementar n.o 68 de 9 de dezembro de 1992. Dispõe sobre o Regime Jurídico dos Servidores Públicos Civis do Estado de Rondônia, das Autarquias e das Fundações Públicas Estaduais e dá outras providências.

SANDERBERG, Rubens. Cadastro Positivo. In: 27ํㅡㄹ Congresso de Direito do Consumidor, 2011, São Paulo.

SOUTO. Elias. Cooperativa de Consumo. Disponível em: <http://www.pampulha.elias.nom.br/index.htm>. Acesso em: 08 mar.2012. 
SUPERIOR TRIBUNAL DE JUSTIÇA. STJ aplica, caso a caso, CDC em relações de consumo intermediário. Ed. Especial. Coordenadoria de Editoria e Imprensa. 19/09/2010. Disponível em:

<http://www.stj.jus.br/portal_stj/publicacao/engine.wsp?tmp.area=398\&tmp.texto=99044> Acesso: 24/03/2012.

Artigo recebido em 28/06/2012 e aprovado para publicação em 14/08/2012. 
A Responsabilidade civil na concessão do empréstimo consignado: uma análise do superendividamento do servidor público no estado de Rondônia 